\title{
Amygdala EphB2 Signaling Regulates Glutamatergic Neuron Maturation and Innate Fear
}

\author{
Xiao-Na Zhu, ${ }^{1,2}$ Xian-Dong Liu, ${ }^{2,3,5}$ Hanyi Zhuang, ${ }^{4,6}$ Mark Henkemeyer, ${ }^{7}$ Jing-Yu Yang, ${ }^{1}$ and $\odot$ Nan-Jie Xu ${ }^{2,3,4,5}$ \\ ${ }^{1}$ Department of Pharmacology, Shenyang Pharmaceutical University, Shenyang 110016, China, ${ }^{2}$ Neuroscience Division, Department of Anatomy, Histology \\ and Embryology, ${ }^{3}$ Department of Biochemistry and Molecular Cell Biology, Shanghai Key Laboratory for Tumor Microenvironment and Inflammation, and \\ ${ }^{4}$ Key Laboratory of Cell Differentiation and Apoptosis of the Chinese Ministry of Education, Shanghai Jiao Tong University School of Medicine, Shanghai \\ 200025, China, ${ }^{5}$ Shanghai Key Laboratory of Reproductive Medicine, Shanghai 200025, China, ${ }^{6}$ The Institute of Health Sciences, Shanghai Institutes for \\ Biological Sciences, Chinese Academy of Sciences/Shanghai Jiao Tong University School of Medicine, Shanghai 200025, China, and ${ }^{7}$ Departments of \\ Neuroscience and Developmental Biology, Kent Waldrep Center for Basic Research on Nerve Growth and Regeneration, University of Texas Southwestern \\ Medical Center, Dallas, Texas 75390
}

The amygdala serves as emotional center to mediate innate fear behaviors that are reflected through neuronal responses to environmental aversive cues. However, the molecular mechanism underlying the initial neuron responses is poorly understood. In this study, we monitored the innate defensive responses to aversive stimuli of either elevated plus maze or predator odor in juvenile mice and found that glutamatergic neurons were activated in amygdala. Loss of EphB2, a receptor tyrosine kinase expressed in amygdala neurons, suppressed the reactions and led to defects in spine morphogenesis and fear behaviors. We further found a coupling of spinogenesis with these threat cues induced neuron activation in developing amygdala that was controlled by EphB2. A constitutively active form of EphB2 was sufficient to rescue the behavioral and morphological defects caused by ablation of ephrin-B3, a brain-enriched ligand to EphB2. These data suggest that kinase-dependent EphB2 intracellular signaling plays a major role for innate fear responses during the critical developing period, in which spinogenesis in amygdala glutamatergic neurons was involved.

Key words: amygdala; EphB2; ephrin-B3; glutamatergic neuron; innate fear; spine

\section{Significance Statement}

Generation of innate fear responses to threat as an evolutionally conserved brain feature relies on development of functional neural circuit in amygdala, but the molecular mechanism remains largely unknown. We here identify that EphB2 receptor tyrosine kinase, which is specifically expressed in glutamatergic neurons, is required for the innate fear responses in the neonatal brain. We further reveal that EphB2 mediates coordination of spinogenesis and neuron activation in amygdala during the critical period for the innate fear. EphB2 catalytic activity plays a major role for the behavior upon EphB-ephrin-B3 binding and transnucleus neuronal connections. Our work thus indicates an essential synaptic molecular signaling within amygdala that controls synapse development and helps bring about innate fear emotions in the postnatal developing brain.

\section{Introduction}

Among key brain nuclei for emotional control, the amygdala plays a unique role in processing threat or motivational events,

Received March 14, 2016; revised Aug. 14, 2016; accepted Aug. 17, 2016.

Author contributions:X.-N.Z. and N.-J.X. designed research;X.-N.Z. and X.-D.L. performed research;X.-N.Z., H.Z., M.H., J.-Y.Y., and N.-J.X. contributed unpublished reagents/analytic tools; X.-N.Z., X.-D.L., J.-Y.Y., and N.-J.X. analyzed data; X.-N.Z., M.H., J.-Y.Y., and N.-J.X. wrote the paper.

This work was supported by National Basic Research Program of China (Program 973 Grant 2014 CB965002 (N.-J.X.), National Natural and Science Foundation of China Grants 91232704 and 31271160 (N.-J.X.) and 81373383 (J.Y.Y), the Program for Professor of Special Appointment (Eastern Scholar) at Shanghai Institutions of Higher Learning (Grant 2013-25 to N.-J.X.), Shanghai Committee of Science and Technology Grant $11 D Z 2260200$ (N.-J.X.), and NIH Grant MH066332 (M.H.). We thank Joshua Sanes for Thy1-GFP-M transgenic mice, Suya Sun for help in virus preparation and injection, Weiguang Li and Tian-Le Xu for assistance in electrophysiological recording setups, and Zi-Jun Deng and Guang-Ni Xu for laboratory technique support. such as fear, anxiety, and stress (Gold et al., 1975; Bergado et al., 2006). Some aspects of these emotional events are driven by the network activity of synaptic connections in the amygdala (McDonald, 1998; Pitkänen et al., 2000; Smith et al., 2000; Sah et al., 2003; Senn et al., 2014). Disruption of amygdala circuits may lead to socioemotional impairment (Zalla and Sperduti, 2013), that

\section{The authors declare no competing financial interests.}

Correspondence should be addressed to either of the following: Dr. Nan-Jie Xu, Shanghai Jiao Tong University School of Medicine, 280 South Chong-qing Road, Shanghai 200025, China; E-mail: xunanjie@sjtu.edu.cn; or Dr. Jing-Yu Yang, Shenyang Pharmaceutical University, 103 Wen-hua Road, Shenyang 110016, China; Email: jingyuyang2006@gmail.com.

DOI:10.1523/JNEUROSCI.0845-16.2016

Copyright $\odot 2016$ the authors $\quad 0270-6474 / 16 / 3610151-12 \$ 15.00 / 0$ 
A

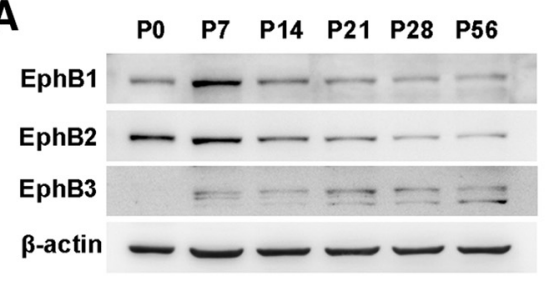

B
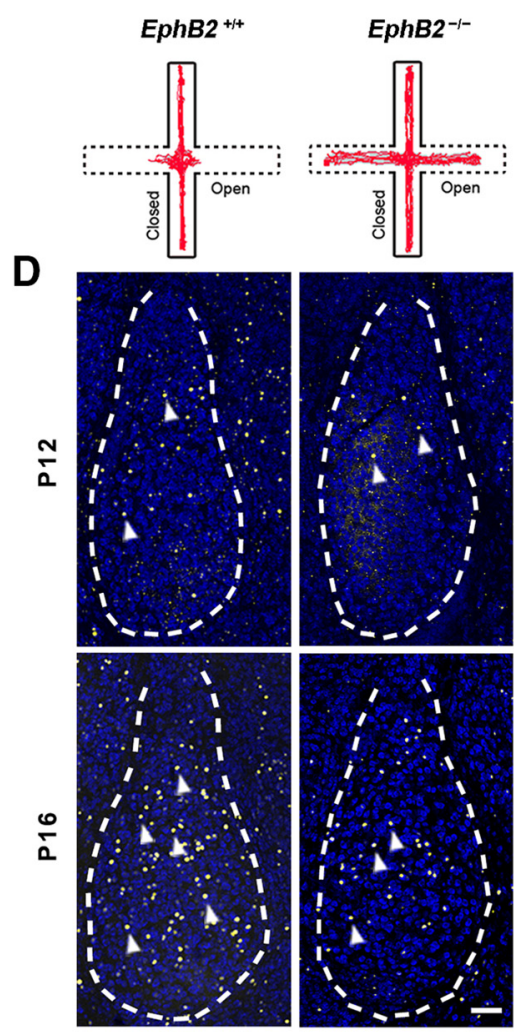

c-Fos Neurotrace

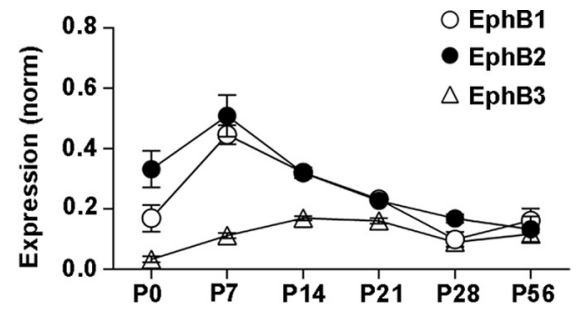

C
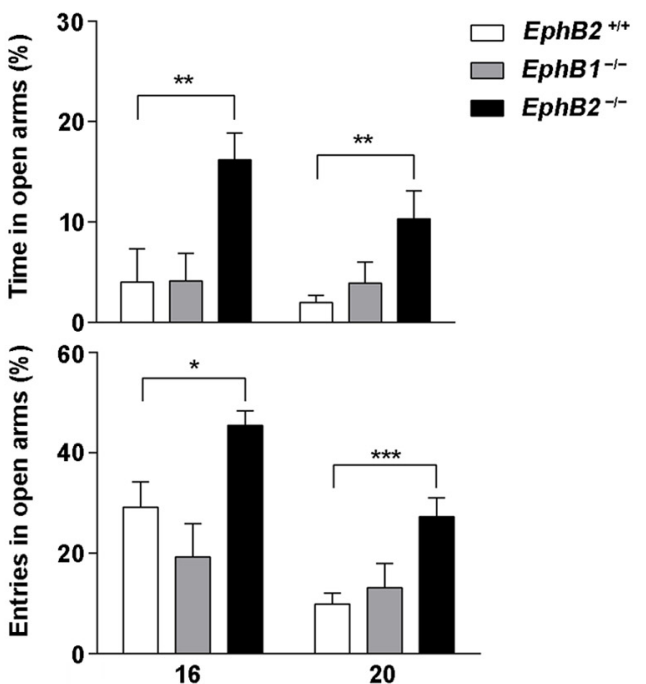

E

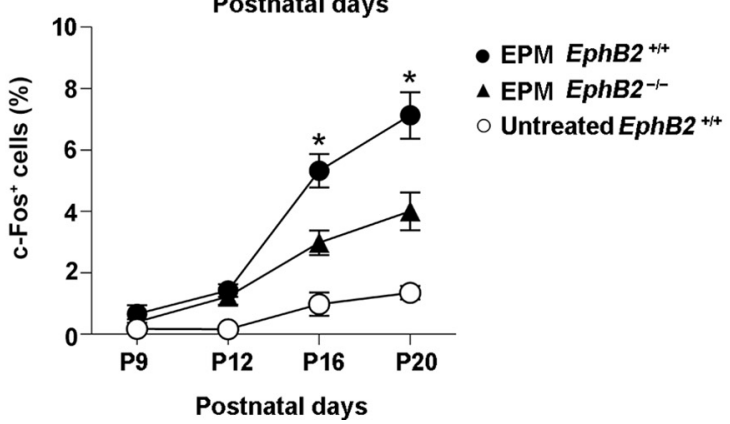

Figure 1. EphB2 is required for innate fear response of juvenile mice in EPM trials. $A$, The expression levels of EphB1, EphB2, and EphB3 proteins were analyzed by Western blotting of amygdala lysates from P0 -P56 wild-type mice. B, Representative animal track of EPM for EphB2 ${ }^{+1+}$ and EphB2 ${ }^{-1-}$ mice at P16.C, EphB2 ${ }^{-1-}$ but not EphB1 ${ }^{-1-}$ mice spent significantly more time and higher entry probability in the open arms than wild types at P16 and P20 ( $n=20-25$ per group). D, c-Fos activation was decreased in BLA neurons of EphB2 ${ }^{-1-}$ mutants (arrowheads) at P16 following EPM behavior trial. Scale bar, $100 \mu \mathrm{m}$. E, Quantification of c-Fos-positive cells (percentage of total neurotrace positive cells) in BLA from P9 to P20 following EPM behavioral trial for $E p h B 2^{+/+}$and EphB2 ${ }^{-1-}$ mice or an untreated control procedure in which the wild-type mice were exposed solely to the context and normal handling but without EPM treatment. $n=6-7$ mice for each group. Data are presented as mean \pm SEM. ${ }^{*} p<0.05 ;{ }^{* *} p<0.01 ;{ }^{* * *} p<0.001$.

were reported in human patients and animal model of neurodevelopmental disorders with various behavioral disturbance, including autism spectrum disorders, anxiety disorders, and schizophrenia (Meyer-Lindenberg et al., 2005; Damsa et al., 2009; Thornton-Wells et al., 2011; Shamir et al., 2012; Chiapponi et al., 2013; Zalla and Sperduti, 2013). Determining the cellular and molecular mechanisms underlying the development of amygdala network is crucial to understanding the plasticity of neuronal responses, and thus the emotional behavior.

The neural circuits are established via synaptic connections that are wired with sophisticated emotional brain nuclei. In cortical regions, principal neurons make local and long-range excitatory projections, whereas GABAergic neurons generally make local circuit inhibitory connections (Jinno et al., 2007; Klausberger and Somogyi, 2008; Mascagni and McDonald, 2009). As a cortical-like structure, the basal lateral amygdala (BLA) contains a similar distribution of neuron types. BLA principal neurons are pyramidal-like excitatory cells with large apical dendrites and smaller basal dendrites (McDonald, 1982b), while various GABAergic neurons exhibit considerable diversity of functional, neurochemical, and anatomical characterization in the BLA that governs primary output signals (Spampanato et al., 2011; Capogna, 2014). The glutamatergic and GABAergic neuronal integration mediates autonomic and behavioral responses associated with fear and anxiety via projections to the brainstem (Tye et al., 2011). In contrast to the large body of evidence linking the amygdala GABAergic neurons to emotional control, however, recent progress in understanding how and in what context the glutamatergic neurons are wired to form functional circuits has been relatively slow.

EphB receptor tyrosine kinases interact with membraneanchored ligands, ephrin-Bs, that are widely expressed in many 
A

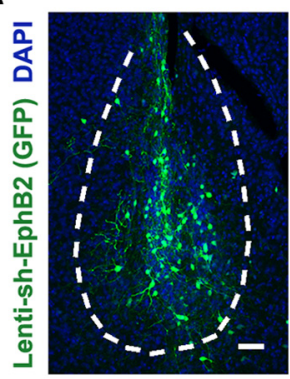

B
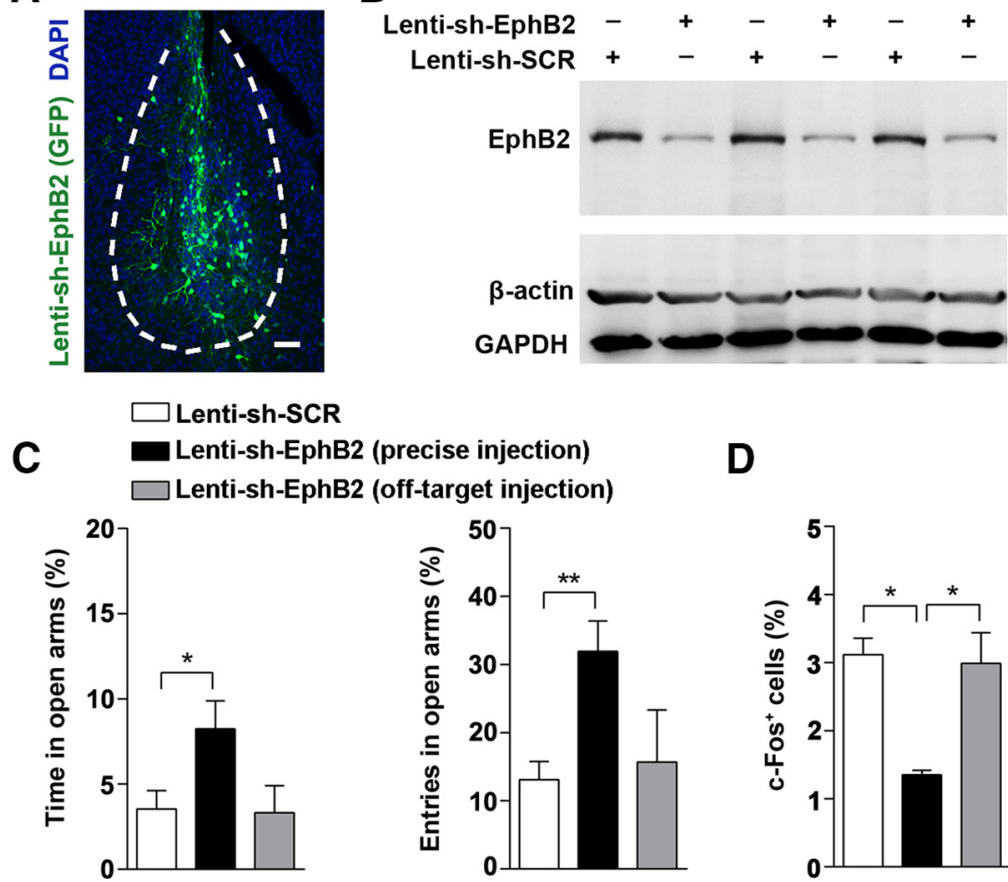

D

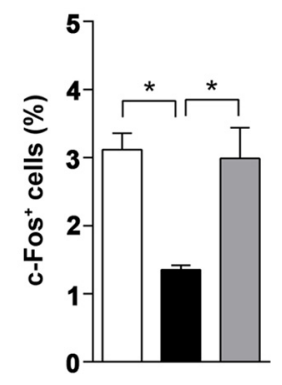

Figure 2. Specifically knockdown of EphB2 in amygdala suppresses innate fear response in EPM trials. $A$, Anti-GFP immunostaining of amygdala showing infected neurons in Lenti-sh-EphB2-GFP (Lenti-sh-EphB2) injected mice. Scale bar, $100 \mu \mathrm{m} . \boldsymbol{B}$, EphB2 protein levels in the entire amygdala injected with either Lenti-sh-EphB2 or scrambled shRNA Lentish-SCR ( $n=3$ per group). $C$, The precise bilateral injections of Lenti-sh-EphB2 in BLA reduced the degree of innate fear responses. The percentage of time and entries in open arms were quantified ( $n=15$ per group). $\boldsymbol{D}$, The precise bilateral injections of Lenti-sh-EphB2 in BLA reduced expression of activated c-Fos at P16. The number of the cells with c-Fos expression in BLA was quantified in Lenti-sh-SCR- and Lenti-sh-EphB2-injected mice following behavior trials. Data are presented as mean \pm SEM. ${ }^{*} p<0.05 ;{ }^{* *} p<0.01$.

brain areas (Yamaguchi and Pasquale, 2004). Upon cell-cell contact, EphBs bind with ephrin-Bs to transduce bidirectional signals that leads to a wide array of developing and functional cellular events (Klein, 2009; Kania and Klein, 2016). Important advances in the study of EphB receptors have been made in the developing nervous system, including axon development (Hindges et al., 2002; Chen et al., 2004; Robichaux et al., 2014), dendritic spine morphogenesis and synapse formation (Dalva et al., 2000; Ethell et al., 2001; Henkemeyer et al., 2003; Kayser et al., 2006, 2008), and synaptic function (Henderson et al., 2001; Nolt et al., 2011). Upon stimulation by ephrin-B ligands, EphB receptors could be phosphorylated in its intracellular section, which thereby activates tyrosine kinase catalytic activity and a cascade of signaling events (Penzes et al., 2003; Hoogenraad et al., 2005; Tolias et al., 2007; Margolis et al., 2010). Our previous studies reveal an essential role of ephrin-B3 for initial defensive behavior (Zhu et al., 2016). Ephrin-B3 serves as a key mediator for hippocampal axon projection into amygdala and plays a transnucleus role for timed coordination of axon targeting and spinogenesis in neonatal brain, suggesting a role of EphB receptor in the connected neurons in the amygdala.

The present study identifies the role of a specific subpopulation of EphB2-expressing neurons in BLA that are essential for spine morphogenesis and innate fear formation. We combined neuronal morphology and activation to clarify the property of EphB2-expressing glutamatergic neurons in the amygdala of juvenile mice. These neurons initiate innate fear response by promoting spine maturation and specific neuron reactions, in which the tyrosine kinase catalytic activity of EphB2 plays a sufficient role. This study thus identifies the intrinsic molecular mechanism underlying amygdala nerve wiring that regulates innate emotions of fear in the postnatal developing brain.

\section{Materials and Methods}

Mice. EphB2 ${ }^{-}$and EphB2 $2^{\mathrm{LacZ}}$ (Henkemeyer et al., 1996), EphB1- (Williams et al., 2003), $E p h B 2^{\text {F620D }}$ (Holmberg et al., 2006), and Efnb3 ${ }^{-}$(Yokoyama et al., 2001) knock-out mice and genotyping methods have been described previously. Mice were crossed with the Thyl-GFP-M transgenic mouse line. Consecutive backcrosses to the CD1 strain were performed to move the mutations to $\mathrm{CD} 1$ background. The ages of mice used are described in the text and figure legends for each experiment. All experiments involving mice were performed in accordance with the U.S. National Institutes of Health Guide for the Care and Use of Laboratory Animals under an Institutional Animal Care and Use Committee approved protocol and at an Association for Assessment and Accreditation of Laboratory Animal Care approved Facility at the Shanghai Jiao Tong University School of Medicine.

Western immunoblots. For Western immunoblots, amygdala samples from postnatal day 0 (P0)-P56 wild-type mice were analyzed. The tissues were dissected in cold PBS, snap frozen in liquid nitrogen, and then lysed in lysis buffer (1\% CHAPS, $137 \mathrm{~mm} \mathrm{NaCl}, 2.7 \mathrm{~mm} \mathrm{KCl}, 4.3$ $\mathrm{mm} \mathrm{Na}_{2} \mathrm{HPO}_{4}, 1.4 \mathrm{~mm} \mathrm{KH}_{2} \mathrm{PO}_{4}$, pH 7.2, $5 \mathrm{~mm}$ EDTA, 5 mM EGTA, 1 mм PMSF, 50 mм NaF, $1 \mathrm{mM} \mathrm{Na}_{3} \mathrm{VO}_{4}$, and protease inhibitors) at $4^{\circ} \mathrm{C}$ for $30 \mathrm{~min}$. Lysates were centrifuged at $4^{\circ} \mathrm{C}$ to remove the insoluble deposit, run on $8 \%$ polyacrylamide gels, and then transferred to nitrocellulose membranes. Membranes were blocked for $2 \mathrm{~h}$ in TBST $(150 \mathrm{~mm} \mathrm{NaCl}, 10 \mathrm{~mm}$ Tris, $0.1 \%$ Tween $20, \mathrm{pH} 7.6$ ) containing $10 \%$ BSA. The primary antibodies goat anti-EphB1 (Santa Cruz Biotechnology, catalog \#sc-68317, RRID: AB_2095521), goat anti-EphB2 (R \& D Systems, catalog \#AF467, RRID: AB_355375), and rabbit anti-EphB3 (GeneTex, catalog \#GTX10617 RRID:AB_381106) were diluted in blocking buffer and incubated overnight at $4^{\circ} \mathrm{C}$. After washing in PBS, the blots were incubated with HRPcongregated secondary antibodies for $1 \mathrm{~h}$ at room temperature. After three washes, the blots were exposed to enhanced chemiluminescence substrate. Quantifications were performed by analyzing relative densities of exposed film using ImageJ (RRID:SCR_003070).

Innate olfactory exposure trial. A 2,5-dihydro-2,4,5-trimethylthiazoline (TMT) odor test (Rosen et al., 2008) was adapted to evaluate innate fear, in which the front door of the exposure PVC tube $(10 \times 2 \mathrm{~cm})$ was made out of Parafilm with a cavity in the center to enable mice to smell specific odors. Mice were initially habituated to the testing tube for $2 \mathrm{~min}$, and were then exposed to water, isoamyl acetate, sesame oil, or TMT (100 $\mu \mathrm{M}$ ) placed in the cavity by cotton ball for $2 \mathrm{~min}$ during the test session. The escape frequencies from the cotton balls stained with specific odors were indexed to evaluate innate fear levels.

Elevated plus maze. All tests were conducted according to a previous study (Zhu et al., 2016). Mice were habituated to handling and were transported from the colony room to the behavioral room for $3 \mathrm{~d}$ before behavioral tests began. The visual ability of mice was checked with a light induced locomotory behavior in a transparent testing chamber, and the time to first body turn away from a bright flashlight $(2 \mathrm{~Hz})$ at one end was recorded. Mice were given $1 \mathrm{~h}$ to habituate after transport to the behavioral room before any tests were conducted. All apparatuses and testing chambers were cleaned with $75 \%$ ethyl alcohol wipes between animals. 
A

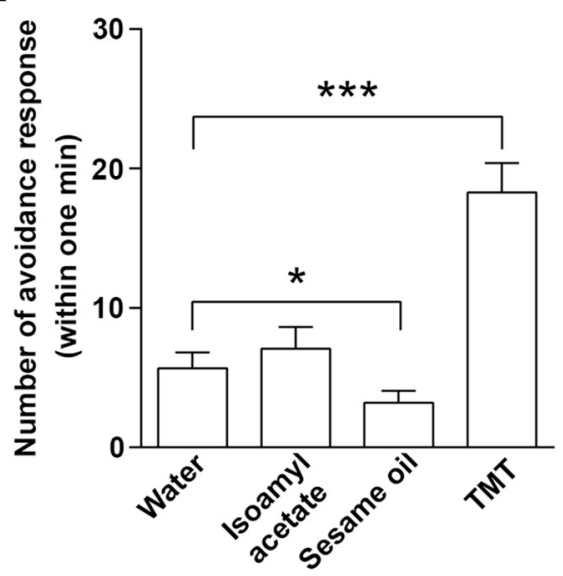

C
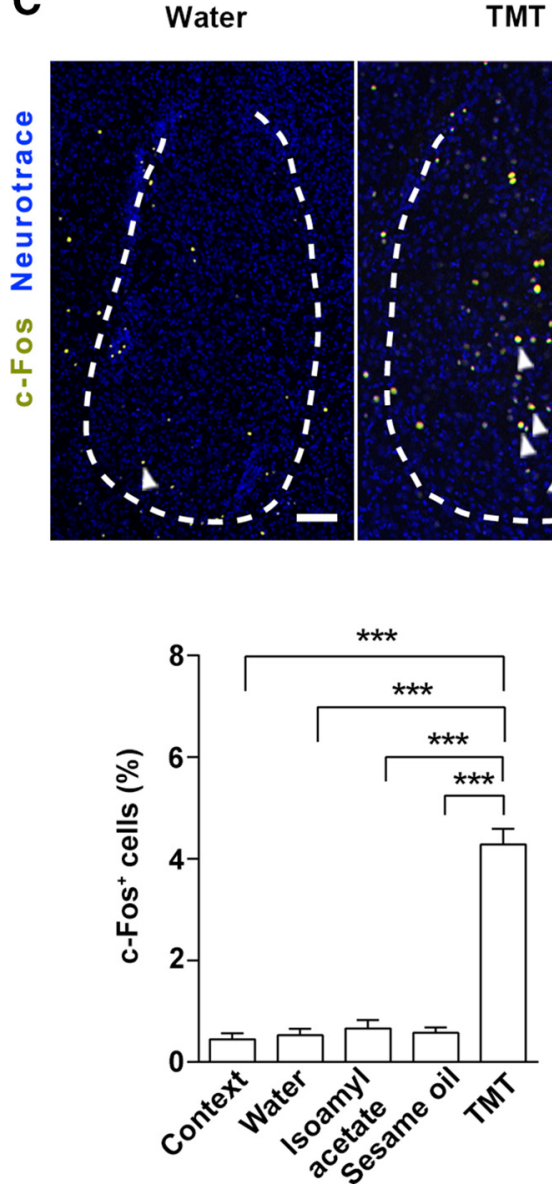

B

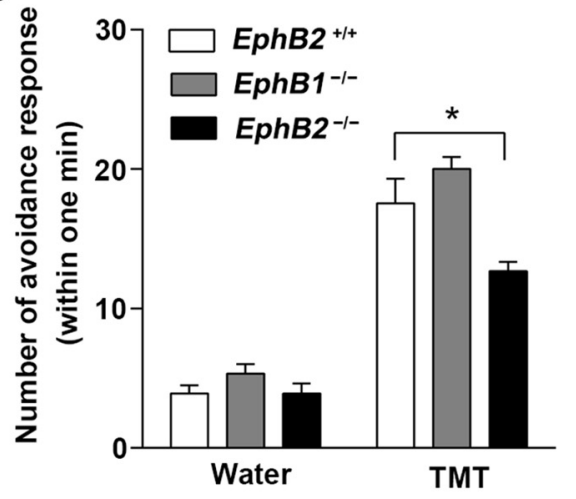

D

EphB2 $^{+/+}$

EphB2 $^{-1-}$
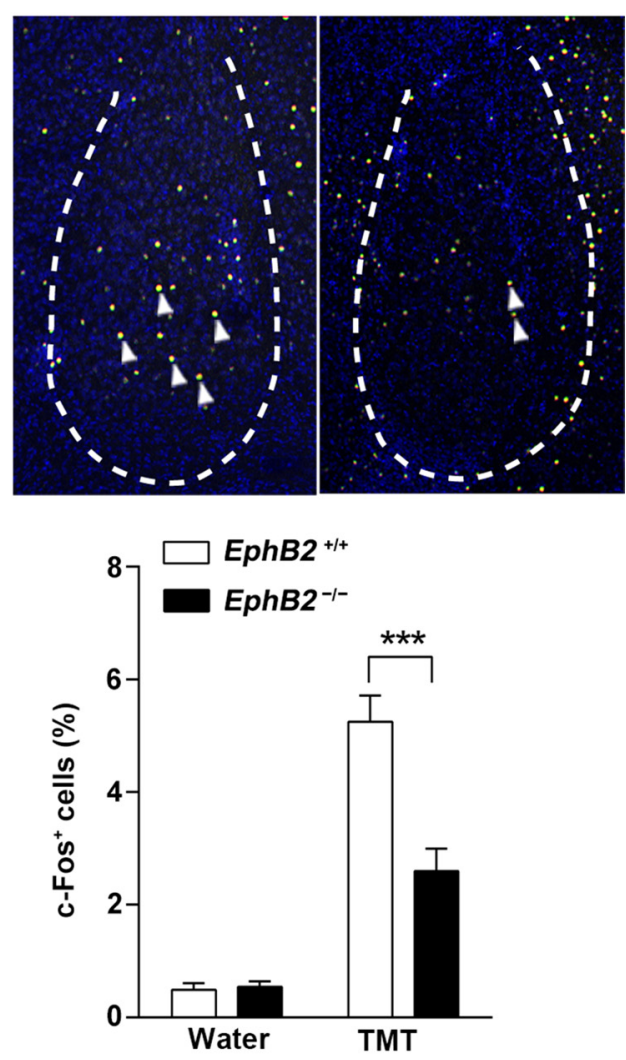

Figure 3. EphB2 is required for innate fear response to predator odor. $A$, Frequency comparison of avoidance from nonaversive or aversive odors (water, isoamyl acetate, sesame oil, TMT) within 1 min was quantified for EphB2 ${ }^{+/+}$mice at P16 $\left(n=10-15\right.$ mice). $\boldsymbol{B}$, Avoidance frequency from the water and TMT within 1 min was quantified for EphB2 ${ }^{+/+}$, EphB1 $1^{-1-}$, and EphB2 ${ }^{-1-}$ mice at P16 ( $n=10-15$ mice per group). C, Quantification of c-Fos-positive cells (indicated by arrowheads, percentage of total neurotrace labeled cells) in BLA of EphB2 ${ }^{+/+}$mice following different treatments (only in experimental tube with water, isoamyl acetate, sesame oil, or TMT; $n=3-4$ mice per group). Scale bar, $100 \mu \mathrm{m}$. $D$, Quantification of c-Fos-positive cells (percentage of total neurotrace labeled cells) in BLA of EphB2 ${ }^{+/+}$, EphB1 ${ }^{-1-}$, and EphB2 ${ }^{-1-}$ mice at P16 following water and TMT trials $(n=$ 3-6 mice per group). Data are presented as mean \pm SEM. ${ }^{*} p<0.05 ;{ }^{* * *} p<0.001$.

The elevated plus maze (EPM) apparatus was made of dark gray plastic and comprised two open arms $(30 \times 7 \times 0.25 \mathrm{~cm})$ opposed to two enclosed arms $(30 \times 7 \times 15 \mathrm{~cm})$ elevated $60 \mathrm{~cm}$ from the floor. Animals were placed in the central area of the apparatus with their head facing an enclosed arm (test duration, $5 \mathrm{~min}$ ). The test was performed in a soundattenuated and temperature-controlled $\left(23 \pm 1^{\circ} \mathrm{C}\right)$ room illuminated by one $40 \mathrm{~W}$ fluorescent bulb placed $3 \mathrm{~m}$ above the apparatus. Digitized video recordings ( 30 frames/s) with EthoVision software (Noldus Infor- mation Technology; RRID:SCR_000441) were used for behavioral analysis. The average velocity and total arm entries were considered an index of locomotor activity, and the percentage of time spent in open arms and the percentage of open-arm entries were used as innate fear indexes.

Immunofluorescence of brain sections. Brain sections were obtained from P16 mice that were processed $3 \mathrm{~h}$ after the EPM or TMT trial for immunofluorescence. Coronal brain slices containing the whole amygdala were sectioned to a $30 \mu \mathrm{m}$ thickness, washed with PBS, and then incubated for 
A

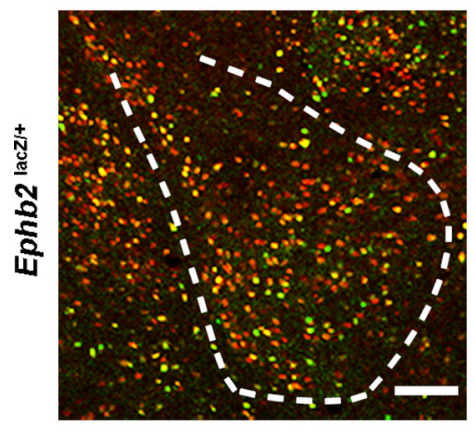

B

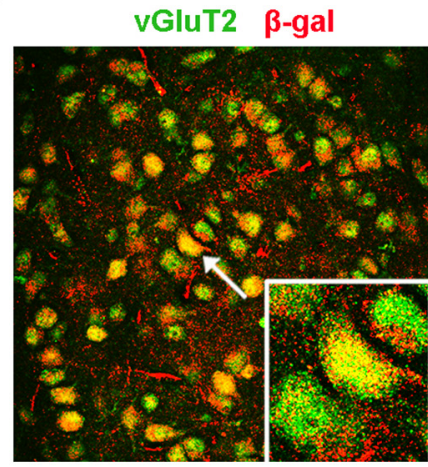

GAD65/67 $\beta$-gal

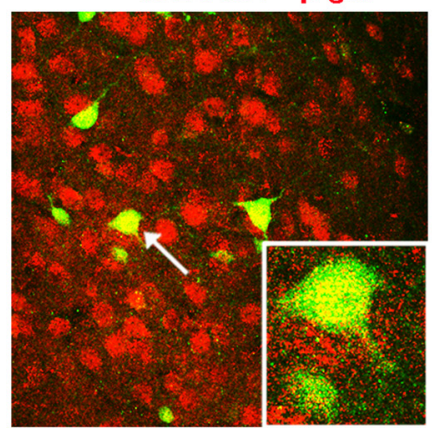

NeuN $\beta$-gal

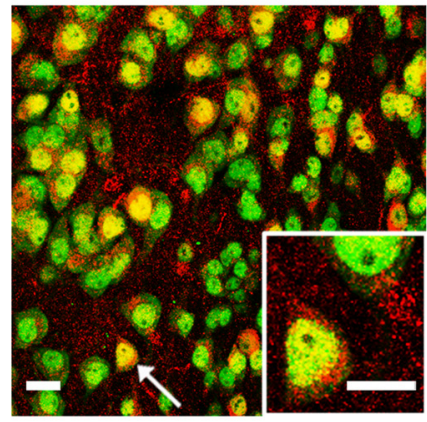

S100 $\beta \quad \beta$-gal

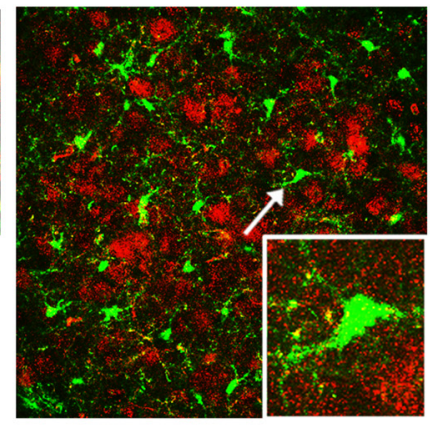

vGluT2 ${ }^{+}$

C

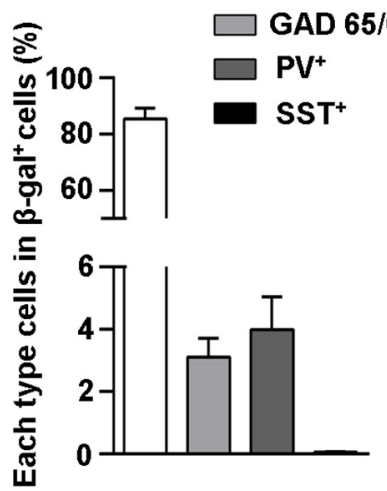

PV $\beta$-gal

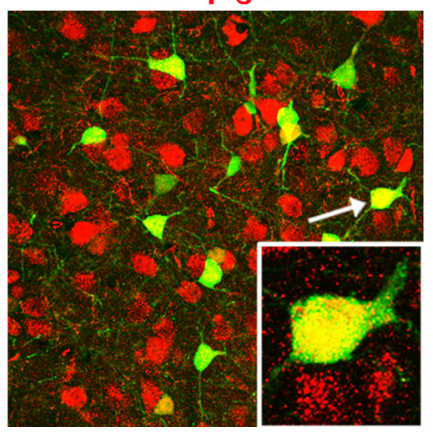

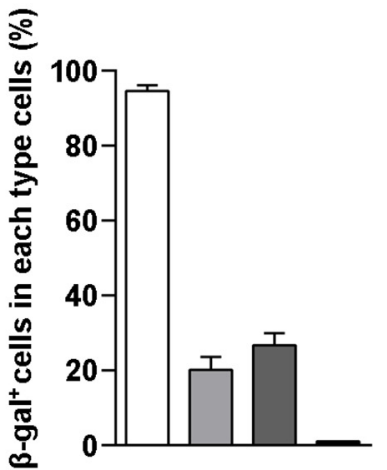

SST $\beta$-gal

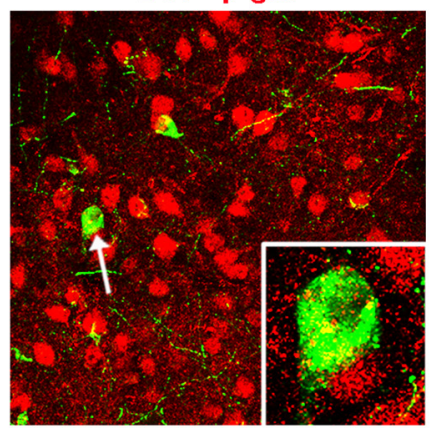

Figure 4. Expression of EphB2 in basolateral amygdala in juvenile mice. $A$, Expression of EphB2 in BLA visualized by immunolabeling of EphB2- $\beta$-gal fusion protein with $\beta$-gal antibody (red) and costaining with NeuN (green) and S100 $\beta$ (green) in EphB2 lacz mice at P16. Scale bars: left, $100 \mu \mathrm{m}$; middle and inset, $10 \mu \mathrm{m}$. B, Expression of EphB2 in BLA visualized by immunolabeling of EphB2- $\beta$-gal fusion protein with $\beta$-gal antibody (red) and costaining with vGluT2 (green), GAD 65/67 (green), parvalbumin (PV, green), and somatostatin (SST, green) in EphB2 ${ }^{\text {lacZ }}$ mice at P16. Arrows indicate cell marker labeled positive cells. C, Quantification of the percentage of vGluT2-, GAD 65/67-, PV-, and SST-positive cells (green) in $\beta$-gal-positive cells (red). $n=3$ mice for per group. Data are presented as mean \pm SEM.

blocking with permable buffter ( $0.3 \%$ Triton X-100 in PBS) containing $10 \%$ donkey serum for 45-60 min. Dual-immunofluorescence experiments were performed using the following primary antibodies: chicken anti- $\beta$-gal (1: 500, Aves Labs, catalog \#BGL-1010; RRID:AB_2313508), rabbit anti-NeuN (Millipore, catalog \#MAB377B; RRID:AB_177621), mouse anti-S100 $\beta$ (Sigma-Aldrich, catalog \#S2532; RRID:AB_477499), goat anti-vGluT2 (Abcam, catalog \#ab101760; RRID:AB_10712030), goat anti-GAD56/67 (Santa Cruz Biotechnology, catalog \#sc-7513; RRID:AB_2107745), mouse anti-parvalbumin (Millipore, catalog \#MAB1572; RRID:AB_11211313), goat antisomatostatin (Santa Cruz Biotechnology, catalog \#sc-7819; RRID: AB_2302603), and rabbit anti-c-Fos (Cell Signaling Technology, catalog \#2250S; RRID:AB_10692514). Primary antibody incubations were performed at $4^{\circ} \mathrm{C}$ for two nights. The sections were rinsed three times (10 min each) in PBS, permeabilized with $0.1 \%$ Tween-20 in PBS, and then incubated at $4^{\circ} \mathrm{C}$ overnight with Alexa Fluor secondary antibodies specific for the primary antibody host. Following incubation with secondary antibodies, sections were rinsed three times (10 min each) in PBS, mounted on gelatin- coated glass slides, and coverslipped using mounting medium (Thermo Fisher Scientific, catalog \#9990402).

Confocal images (Leica SP8) were used to analyze dual-immunofluorescence patterns. Analysis and quantitative analysis of duallabeled neurons in the BLA was performed with ImageJ software (RRID:SCR_003070). For each pair of primary antibodies, immunoreactive neurons from representative sections containing the BLA were counted and analyzed for dual labeling. Colocalization was determined by capturing confocal $Z$ stack images and counting the number of neurons colocalizing the two markers in all focal planes.

For quantitative analysis for the percentage of c-Fos-positive cells and shape of spine, a procedure was adapted from our previous study (Sun et al., 2014). Approximately 15-30 neurons from three to four mice were analyzed for each genotype and age sample. To classify the shape of neuronal spines in slices, we used the NeuronStudio software package (RRID:SCR_013798) and an algorithm from Rodriguez et al. 
(2008) with the following cutoff values: Aspect ratio thin (crit) $=2.5$, Head to neck ratio $_{(\text {crit })}=1.3$, Head diameter $($ crit) $=0.4$ $\mu \mathrm{m}$. The protrusions with length $0.2-3.0 \mu \mathrm{m}$ and maximum width of $3 \mu \mathrm{m}$ were counted. For quantitative analysis for the strength of linear dependence between c-Fos immunofluorescence and the percentage of the spines with indicated heard diameter in BLA, each double-labeled neuron (Thyl-GFP and c-Fos) located in BLA was counted as a single data point. Acquisition of the images as well as morphometric quantification was performed under "blinded" conditions.

In vitro electrophysiology. Brain coronal slices were prepared from naive EphB2 $2^{+1+}$ and EphB2 $2^{-1-}$ mice at P16. Brains were dissected quickly and chilled in ice-cold artificial CSF containing the following (in $\mathrm{mm}$ ): $125 \mathrm{NaCl}, 2.5 \mathrm{KCl}, 2 \mathrm{CaCl}_{2}, 1 \mathrm{MgCl}_{2}, 25$ $\mathrm{NaHCO}_{3}, 1.25 \mathrm{NaH}_{2} \mathrm{PO}_{4}$, and 12.5 glucose, with $95 \% \mathrm{O}_{2} / 5 \% \mathrm{CO}_{2}$. Coronal brain slices containing amygdala (300 $\mathrm{mm}$ thick) were prepared with a vibratome and transferred to a chamber with bubbling $95 \% \mathrm{O}_{2}$ and $5 \%$ $\mathrm{CO}_{2}$ at $35^{\circ} \mathrm{C}$ for $30 \mathrm{~min}$ and then maintained at room temperature $\left(22-25^{\circ} \mathrm{C}\right)$. Neurons were targeted for whole-cell patch-clamp recording with borosilicate glass electrodes having a resistance of 5-8 $\mathrm{M} \Omega$. The electrode internal solution was composed of the following (in mM): $115 \mathrm{CsMeSO}_{3}, 10$ HEPES, $2.5 \mathrm{MgCl}_{2} \cdot 6 \mathrm{H}_{2} \mathrm{O}, 20 \mathrm{CsCl}_{2}, 0.6$ EGTA, 10 Na phosphocreatine, $0.4 \mathrm{Na}-\mathrm{GTP}$, and $4 \mathrm{Mg}$ ATP. Amygdala neurons were selected from the BLA region. For mEPSC recording, tetrodotoxin $(1 \mu \mathrm{M})$ and picrotoxin $(100 \mu \mathrm{M})$ were included in the external solution. Cells were held at $-70 \mathrm{mV}$. Miniature responses were acquired with a Multiclamp 200B at 10 $\mathrm{kHz}$. Before mEPSC detection and analysis, current traces were low-pass filtered at 5 $\mathrm{kHz}$. Events having an amplitude of $2 \times$ root mean square noise were detected using Mini Analysis software (RRID:SCR_002184).

Virus constructs generation and stereotaxic injection. For adeno-associated virus (AAV2) generation, EphB2 (AAV-HA-EphB2) and lenti-EphB2-shRNA (Lenti-sh-EphB2, sequence ACGGACAAGCTACAACACT), constructs were subcloned as described previously (Xu et al., 2011; Sun et al., 2014).

For stereotaxic injection, pups (P1-P2) were subjected to the operative procedure using aseptic technique. They were gently anesthetized with ice for 5-10 min while placed prone onto a stereotaxic frame. For bilateral BLA injection, lenti-sh-EphB2 or AAV2-HA-EphB2 was injected into BLA ( $1.5 \mathrm{~mm}$ posterior and $2 \mathrm{~mm}$ left to the bregma, and $1.0 \mathrm{~mm}$ deep into the skull surface). After injection, the hand-held needle was kept in place for an additional 5 min to avoid backflow of virus containing solution. Following injection, the pups were collected on a $37^{\circ} \mathrm{C}$ warm plate for recovery. After regaining mobility, the injected pups were rolled in home cage bedding and returned to their mother as a group. Mice were allowed to recover for 10 to $15 \mathrm{~d}$ before starting the experiments. At the end of the experiment, mice used in behavioral tests were killed by perfusion, and the injection sites were evaluated for each animal.

Statistical analysis. The results are presented as mean \pm SEM. Statistical differences were determined by Student's $t$ test for two-group com- parisons or ANOVA followed by Dunnett's test for multiple comparisons among more than two groups.

\section{Results}

$\mathrm{EphB2}$ is required for innate fear responses in juvenile mice We first analyzed the expression of EphB receptors in the amygdala throughout postnatal development and found that EphBs, in particular, EphB1 and EphB2, were highly expressed at early neonatal stage of amygdala and decline gradually thereafter (Fig. 1A). We then asked whether EphB2 is required for the innate fear reactions elicited in amygdala of the neonatal brain. To identify the initial onset of innate fear behavior, we performed behavioral examination through either a testing trial with an EPM or an exposure trial to predator odor TMT (Morrow et al., 2002; Kobayakawa et al., 2007; Fendt and Endres, 2008). We chose these behavioral paradigms because we are mostly interested in innate rather than the learned fear behavior that has been reported previously (Cruz et al., 2015; Dines et al., 2015). The behavioral trials 
A
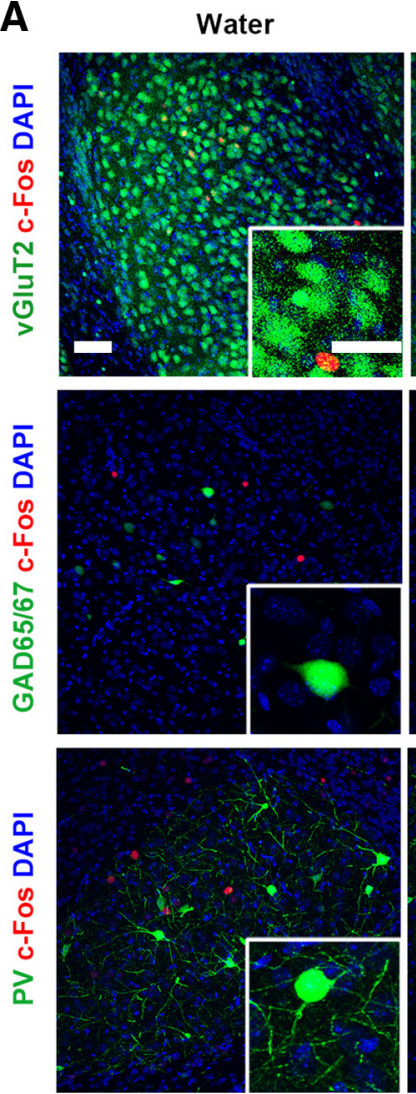

B

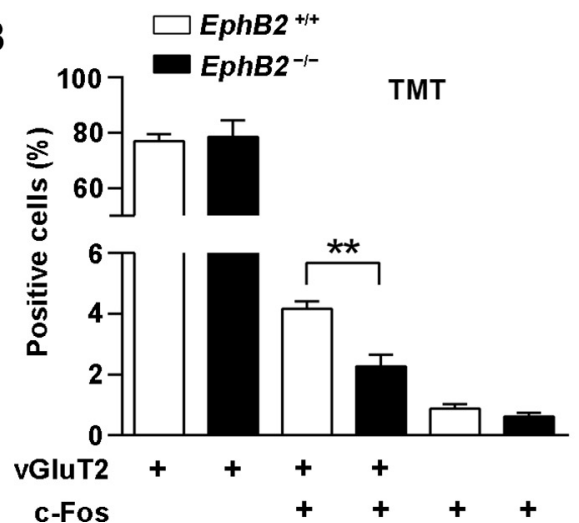

Isoamyl acetate
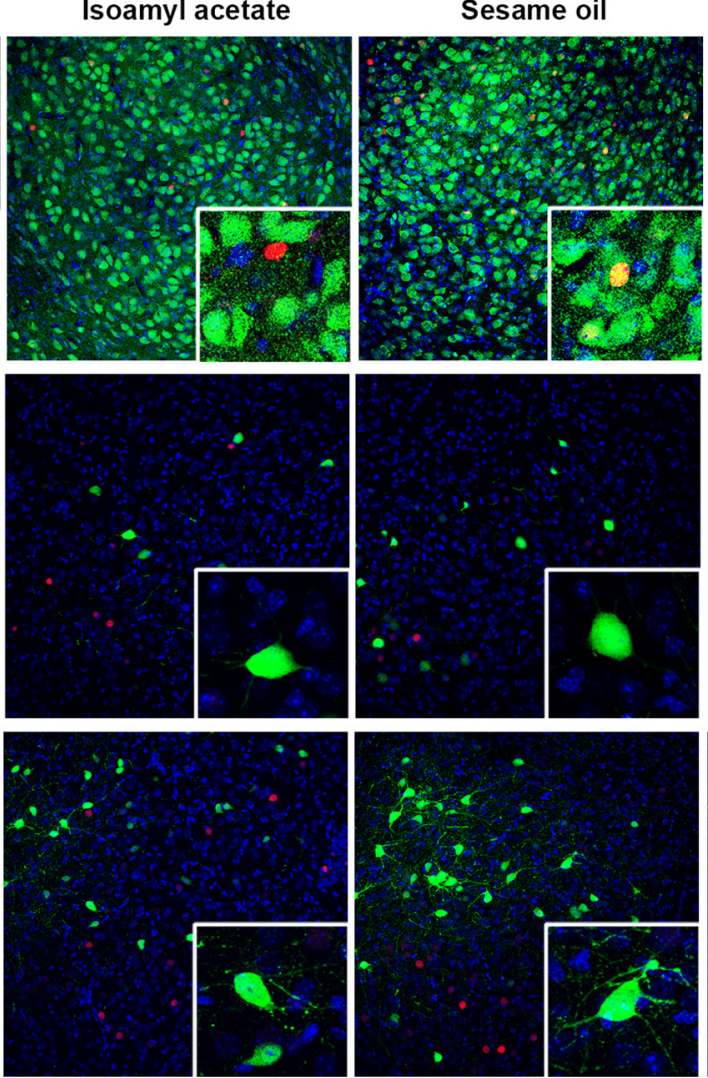

C

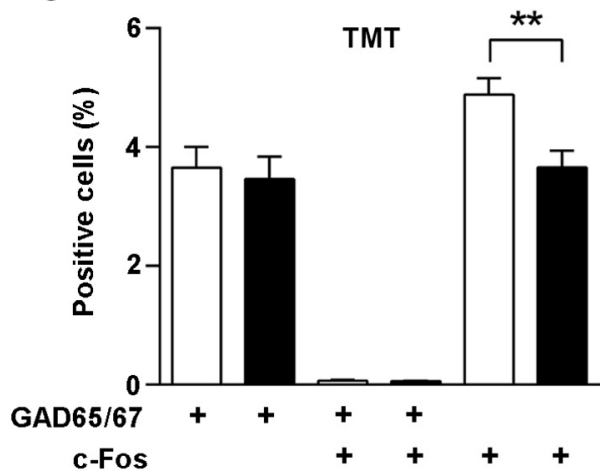

TMT
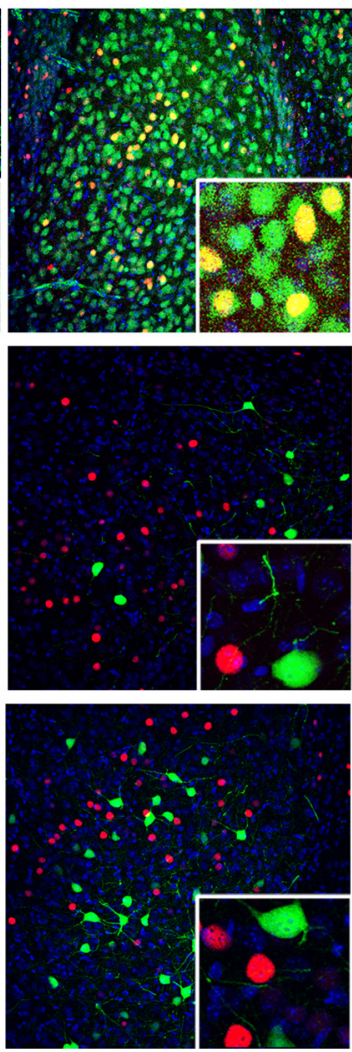

Figure 6. Amygdala EphB2-expressing glutamatergic neurons are responsible to fear elicitation by predator odor. $A$, Confocal images of the BLA from wild-type mice at P16 following different treatments (water, isoamyl acetate, sesame oil, or TMT). The brain slices were stained for c-Fos (red) with vGluT2 (green), GAD65/67 (green), or parvalbumin (PV, green) as indicated. Scale bars, 20 $\mu \mathrm{m} . \boldsymbol{B}, \boldsymbol{C}$, The proportion of the c-Fos-positive cells located in the vGluT2-positive cells, but not in GAD65/67-positive cells, were significantly reduced in the mutants after TMT trial. $n=3$ mice for each group. Data are presented as mean \pm SEM. ${ }^{* *} p<0.01$

were followed with measurement of c-Fos expression in amygdalas of litters, which indicates neuron reaction to aversive stimuli in juvenile mice. In the EPM trial, EphB2 ${ }^{-/-}$mice showed a significant longer exploring time and more entries in open arm of the maze from P16 compared to wild-type or EphB1 $1^{-1-}$ mice (Fig. $1 B, C$ ). Consistently, a dramatic increase in the number of c-Fos-positive cells in BLA was also observed from P16 upon the EPM, and the c-Fos activity was decreased significantly in EphB2 $2^{-/-}$mice (Fig. $1 D, E$ ).

To further verify the spatial specificity of EphB2 for innate fear, we generated lentiviral vectors expressing both green fluorescent protein (GFP) and anti-EphB2 shRNA (Lenti-sh-EphB2) or scrambled control shRNA (Lenti-sh-SCR) and then bilaterally injected these lentiviruses into the amygdala of wild-type mice at
$\mathrm{P} 0-\mathrm{P} 1$ to see if knocking down EphB2 in amygdala could mimic the behavioral defect in EphB2 $2^{-1-}$ mice (Fig. $2 A$ ). In the tissue lysates of the amygdala, Lenti-sh-EphB2 remarkably reduced EphB2 protein levels at P16 (Fig. 2B). The mice were subjected to EPM trial testing at P16, and the mice expressing Lenti-sh-EphB2 in amygdala exhibited abnormal innate defensive behavior compared to Lenti-sh-SCR-injected control mice, which also showed a reduction in c-Fos activation in amygdala (Fig. 2C,D). However, off-target injections that missed the amygdala had minimal effects on innate fear behavior and c-Fos activation (Fig. 2C,D).

In TMT behavioral paradigms, likewise, upon the TMT odor exposure that induced significant avoidance responses at P16 in the juvenile mice (Fig. $3 A$ ), EphB2 $2^{-1-}$ exhibited a defective re- 
sponses compared with wild-type mice or EphB1 ${ }^{-/-}$mice (Fig. 3B). The altered fear responses were reflected specifically by a reduction in c-Fos activity of BLA neurons, indicating a defective reaction to threat stimuli in corresponding neurons (Fig. $3 C, D)$ consistent with the EPM results.

\section{Amygdala glutamatergic neurons respond to fear elicitation}

To further characterize the neuronal role for EphB2 in BLA, we used the EphB2 ${ }^{\text {LacZ }}$ knock-in mutant containing a membranelocalized C-terminal truncated EphB2- $\beta$ galactosidase (EphB2- $\beta$-gal) fusion protein that is expressed in the same temporal, spatial, and subcellular pattern as the endogenous wild-type protein and provides for a high signal-to-noise ratio reporter for EphB2 expression (Henkemeyer et al., 1996). Our analysis revealed that EphB2 was specifically expressed in amygdala neurons but not in astrocytes (Fig. 4A). We identified the subpopulation of EphB2-expressing neurons by costaining with $\beta$-gal and neuronal excitatory or inhibitory markers, and found that over $80 \%$ of EphB2-expressing neurons expressed vGluT2, a marker for excitatory neurons. We further analyzed the EphB2-expressing cells with inhibitory/ interneuronal markers and found that EphB2-expressing neurons also involved a subset of GAD65/67 and parvalbumin cells, but did not overlap with somatostatin cell populations (Fig. $4 B, C$ ). These data suggest that EphB2 is expressed in differential subpopulations of amygdala neurons.

We next addressed which neuronal subpopulation in BLA is responsible for the elicited fear. We performed c-Fos staining in EPM-tested juvenile mice and found that c-Fos activation followed by the behavior trial occurred mainly in vGluT2-expressing neurons but not in GAD65/67-expressing (Fig. 5A) or parvalbumin-expressing neurons (data not shown). We further detected the role of EphB2 in c-Fos activation in the two types of neurons and observed a reduction of c-Fos activity in vGluT2-positive neurons but not in vGluT2-negative neurons in EphB2 ${ }^{-1-}$ mice compared to wildtype mice (Fig. $5 B$ ). In contrast, a reduction of c-Fos activity was observed in GAD65/ 67-negative neurons but not in GAD65/67positive neurons (Fig. 5C), which was in agreement with the activation of glutamatergic neurons. The result was also verified with the TMT-exposure trial, that the defective c-Fos activation caused by EphB2 deletion occurred in vGluT2-expressing neurons, rather than GAD65/67-expressing (Fig. 6A-C) or parvalbuminexpressing neurons (data not shown). These data indicate that EphB2-mediated innate fear behaviors in juvenile mice are mainly ${ }^{* *} p<0.01 ; * * * 0.001$.
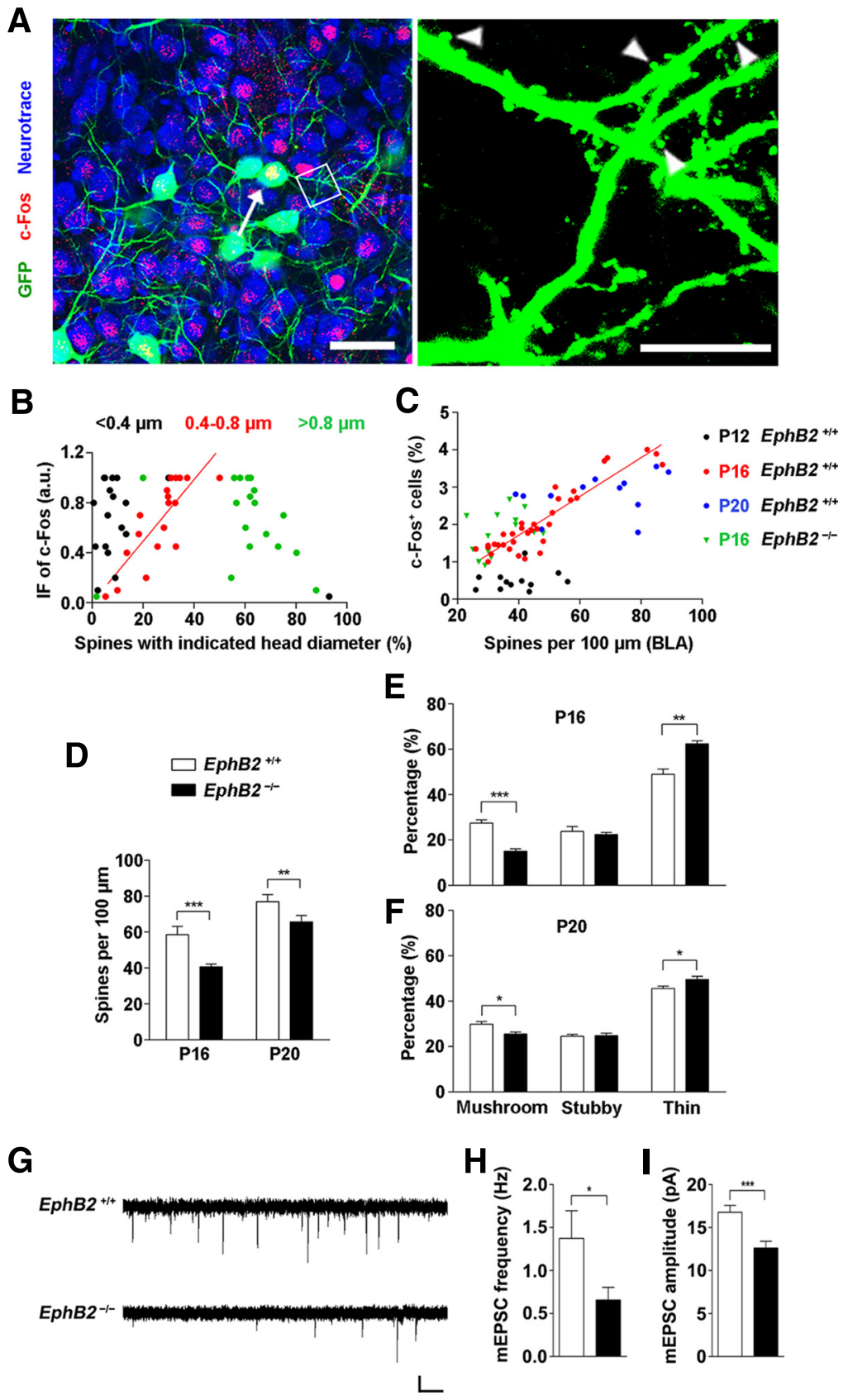

Figure 7. EphB2 mediates spine morphogenesis in amygdala of juvenile mice. $A$, GFP labeled c-Fos-positive neurons (arrow indicates the neuron) and c-Fos-negative neurons in BLA at P16. Scale bars: left, $20 \mu \mathrm{m}$; right, $5 \mu \mathrm{m}$. Arrowheads indicate the spines. $\boldsymbol{B}$, Correlation of the immunofluorescence (IF) intensity of c-Fos with percentage of spines with indicated diameter in c-Fos-positive neurons. The three types of spines are $<0.4 \mu \mathrm{m}$ (black dots; $r^{2}=0.13$ ), $0.4-0.8 \mu \mathrm{m}$ (red dots; $r^{2}=0.66, p<0.001$ ), and $>0.8 \mu \mathrm{m}$ (green dots; $r^{2}=$ 0.09 ), respectively. $n=18$ neurons. $C$, The percentage of activated c-Fos-positive cells was correlated with mean of spine density (number of spines per $100 \mu$ m dendrite) in the BLA area of individual brain slice at P16 (red dots), but not at P12 (black dots) or P20 (blue dots). The correlation was disrupted in EphB2 ${ }^{-1-}$ mice at P16 (green triangles). D, EphB2 mutant showed low spine density in BLA neurons at P16. Quantification of spine density in EphB2 ${ }^{+/+}$and EphB2 $2^{-1-}$ mutants atP16 and P20 ( $n=15$ per group) is shown. $\boldsymbol{E}, \boldsymbol{F}$, Quantification of the percentages of mushroom, stubby, and thin spine types in BLA neurons at P16 and P20. $n=15$ per group. $G$, $\mathrm{mEPSC}$ were recorded in BLA neurons from EphB2 ${ }^{+/+}$and EphB2 $2^{-/-}$mice at P16. Calibration: $10 \mathrm{pA}, 1 \mathrm{~s}$. $\boldsymbol{H}, \boldsymbol{I}$, Quantification of mEPSC frequency $(\boldsymbol{H})$ and amplitude $(I)$ for BLA neurons from EphB2 ${ }^{+/+}$and EphB2 ${ }^{-I-}$ mice. $n=18$ neurons. Data are presented as mean \pm SEM. ${ }^{*} p<0.05$;

attributable to the role of glutamatergic neurons but not that of GABAergic neurons in the neonatal brain.

\section{EphB2 mediates spinogenesis in amygdala}

The next question we addressed was the specific morphological property of these neurons that accounts for the c-Fos activation. 
A
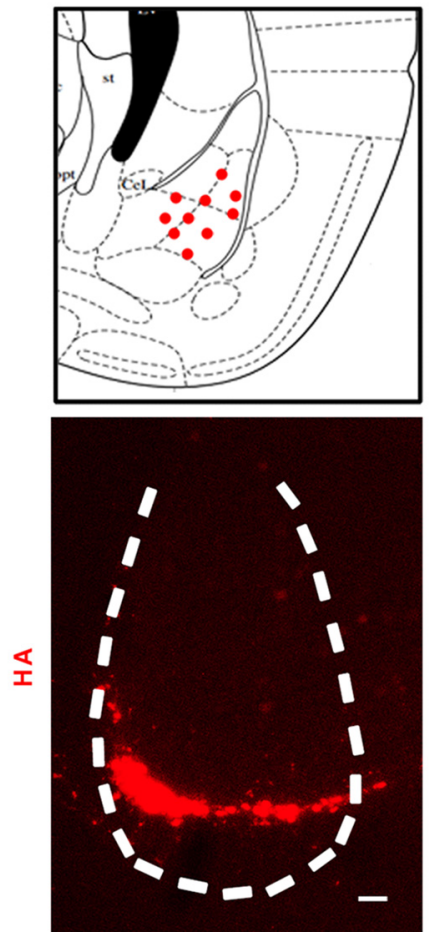

B

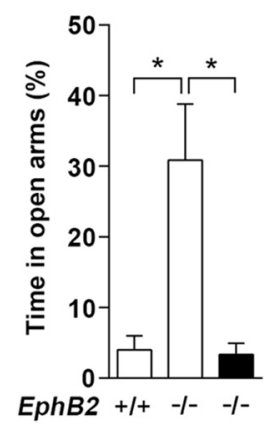

C

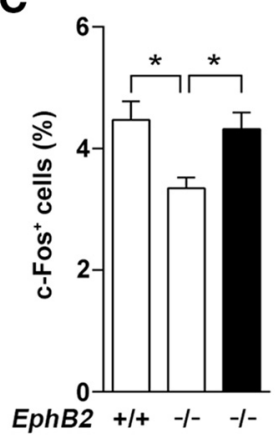

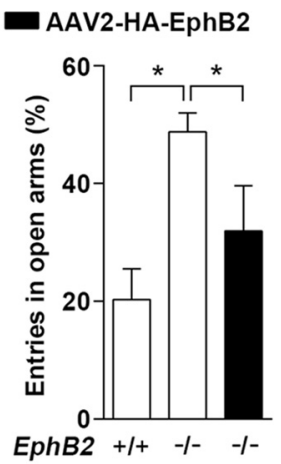

D

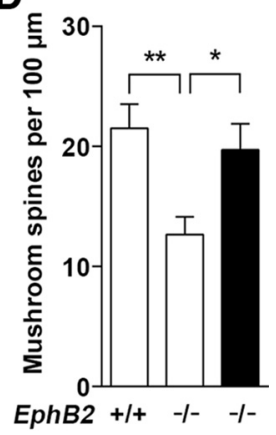

Figure 8. EphB2 overexpression in amygdala is sufficient to rescue innate fear behavior and spine morphogenesis in EphB2 ${ }^{-}$ - mice. $\boldsymbol{A}$, Mode of AAV2-HA-EphB2 stereotaxic injections that hit the BLA (red dots). An example of AAV2-mediated EphB2 expression in BLA is shown by immunofluorescence with anti-HA antibody. Scale bar, $100 \mu \mathrm{m} . \boldsymbol{B}, \boldsymbol{C}$, AAV2-HA-EphB2 injections that hit the BLA bilaterally decreased the degree of innate fear and rescued expression of activated c-Fos at P16. The percentage of time and entries in open arms were quantified ( $n=15$ per group). The number of the cells with c-Fos expression in the BLA was quantified in AAV2-tdTomato- and AAV2-HA-EphB2-injected mice following behavior trials. D, AAV2-HA-EphB2 injections that hit the BLA bilaterally rescued expression of activated $c-$ Fos and the density of mushroom spines at P16. Data are presented as mean \pm SEM. ${ }^{*} p<0.05 ;{ }^{* *} p<0.01$.

We used a Thy1-GFP-M transgenic mouse reporter line to examine the morphogenesis of c-Fos-positive neurons ( $~ 20 \%$ of GFPlabeled neurons) and found these neurons present many more mushroom-shaped spines with a narrow neck and large head than c-Fos-negative neurons and could be classified into three types according to their head diameters (Fig. 7A). By plotting c-Fos immunofluorescence levels of the amygdala neurons versus the percentage of various type distributions, we observed a considerable variability in the population of mushroom-shaped spines with a head diameter range of $0.4-0.8 \mu \mathrm{m}$, and the amount of these spines was correlated with the neuronal reaction $\left(r^{2}=0.66, p<0.001\right.$; Fig. $\left.7 B\right)$. To further determine whether the spinogenesis in the BLA area is related to the EphB2-mediated fear behavior, we examined the density of spines along the dendrites of a developmental variety of BLA neurons and analyzed the density of c-Fos-activated cells as well in the amygdala of the identical brain slice. We found that the spine morphogenesis and the number of c-Fos-positive cells were correlated, and the correlation was restricted to P16 rather than earlier or later time points. The correlation was disrupted completely in EphB2 $2^{-1-}$ mice (Fig. 7C). We thus examined the early morphological changes of the density of spines and the various spine types in BLA at P16 and P20. The neurons in EphB2 ${ }^{-1-}$ mice showed that the density of total spines was reduced in mutants analyzed at P16 and P20 compared to that of wild-type mice (Fig. 7D). A significant reduction in the fraction of the mushroom spines and proportional increase in the fraction of thin spines were also

observed in EphB2 $2^{-1-}$ mice at P16 and P20 (Fig. 7E,F). These results indicate that threat-elicited innate neuronal response was likely associated with a subset of responsive BLA neurons with mushroom spinogenesis that was controlled by EphB2.

To examine whether the changes in spine density resulted in changes in synapse number, we recorded miniature EPSCs (mEPSCs) in BLA neurons in acute brain slices using whole-cell patch-clamp recordings. The neurons in EphB2 $2^{-/-}$ mice exhibited a greatly reduced mEPSC frequency and amplitude compared to those in the wild-type mice (Fig. 7G-I). These results provide further evidence for a reduction in the number of excitatory synapses in BLA neurons in the absence of postsynaptic EphB2.

If downregulation of EphB2 is responsible for a reduced level of innate fear, then overexpression of EphB2 should be able to rescue the abnormal innate fear and increase mushroom spines in EphB2 ${ }^{-1-}$ mice. To test this prediction, we overexpressed EphB2 protein through injecting an AAV encoding EphB2 (AAV2-HA-EphB2) into the amygdala of EphB2 $2^{-1-}$ mice at $\mathrm{P} 0-\mathrm{P} 1$ to see whether the deficit was rescued (Fig. 8A). The mice were subjected to an EPM trial test at P16, and the mice expressing AAV2-HA-EphB2 in the BLA exhibited normal innate defensive behavior compared to AAV2-tdTomato-injected control mice, accompanied by a restoration in c-Fos activation in amygdala (Fig. $8 B, C$ ). Furthermore, the defective mushroom spine morphogenesis was also rescued compared to that of control AAV-injected EphB2 $2^{-/-}$mice at P16 (Fig. 8D).

\section{EphB2 forward signaling regulates fear behavior}

As a binding molecule of the ephrin-B ligands, EphB2 is capable of transducing bidirectional signals by either serving as a receptor to transduce signals into the cells it is expressed on, which is forward signaling, or serving as ligand to bind and stimulate ephrin-B-expressing cells, which is reverse signaling (Henkemeyer et al., 1996), as demonstrated to be essential for dendritic development of hippocampal neurons (Henkemeyer et al., 2003; $\mathrm{Xu}$ et al., 2011). Therefore, to verify the specific requirement of EphB2 expression in the amygdala for mediating this effect, we used EphB2 ${ }^{\text {LacZ/lacZ }}$ mice to perform the EPM test. These EphB2 mutant mice express a truncated EphB2- $\beta$-gal fusion protein that retains the extracellular and transmembrane domains to provide ligand-like activity, but are unable to transduce forward intercellular signals (Henkemeyer et al., 1996). Unlike the wild-type mice, EphB2 ${ }^{\text {LacZ/lacZ }}$ mice showed no difference compared to EphB2 ${ }^{-1-}$ mice at P16 (Fig. 9A). These data indicate that EphB2 forward signaling is required for the innate fear behaviors.

Finally, to further evaluate the sufficiency of EphB2 receptormediated signaling in fear behavior, we used $E f n b 3^{-1-}$ mice, which ablate the ephrin-B3 ligand (Xu et al., 2011) and exhibit a reduced fear response (Zhu et al., 2016), and cross-bred them with $E p h B 2^{\mathrm{F} 620 \mathrm{D} / \mathrm{F} 620 \mathrm{D}}$ mice, with a constitutively active receptor 
form of EphB2 possessing ligandindependent catalytic activity (Holmberg et al., 2006). The mice were subjected to the EPM trial at P16 to address whether EphB2 forward signal transduction recapitulates the innate fear formation in $E_{n} 3^{-1-}$ mice. The EphB2 $2^{\mathrm{F} 620 \mathrm{D} / \mathrm{F} 620 \mathrm{D}}$ mice per se showed no difference compared to the wild-type mice in behavior (Fig. 9A). However, we observed that the innate fear responses and c-Fos expression in amygdala were significantly recovered in Efnb3 $3^{-1-} ; E p h B 2^{\mathrm{F} 620 \mathrm{D} / \mathrm{F} 620 \mathrm{D}}$ compound mutants compared with $E f n b 3^{-1-} ; E p h B 2^{+/+}$control mice (Fig. $9 B, C)$. Furthermore, we examined for spine morphology and found a dramatic increase in densities of both total and mushroom spines in GFP-labeled cells within the BLA area of $E f n b 3^{-1-}$; $E p h B 2^{\mathrm{F} 620 \mathrm{D} / \mathrm{F} 620 \mathrm{D}}$ mutants compared to that of $E f n b 3^{-/-}$; EphB2 $2^{+/+}$mice (Fig. 9D). No difference was observed between two groups in either c-Fos activation or spine number in hippocampal CA1 neurons (Fig. 9C,D). These data indicate that kinase activity-mediated EphB2 intracellular signaling is sufficient to elicit innate fear responses in juvenile mice.

\section{Discussion}

In the present study, we uncover a key molecular mechanism underlying amygdala associated innate fear behavior. We identify that EphB2 is expressed specifically in the amygdala during postnatal developing period and is required for fear formation in juvenile mice (Figs. 1-3). The essential role of EphB2 is likely attributable to its expression in excitatory neurons rather than inhibitory neurons in BLA (Figs. 4-6). The results further demonstrate that EphB2 coordinates spinogenesis and neuron activity in amygdala responding to threat stimuli (Figs. 7, 8). Moreover, rescue of EphB2 catalytic activity restored the neuron activity and innate behavior (Fig. 9). To the best of our knowledge, this is the first evidence dissecting neuronal molecular signaling for amygdala mediated innate fear in juvenile mice.

Amygdala-associated neural circuits serve as the functional basis of negative emotions and memory for fear elicited in the brain. Our study is distinct from the studies for neuronal pathways that regulate the acquisition and relapse of fear (Gross and Canteras, 2012) relying on the context associated learning processes (LeDoux, 2003; Phelps and LeDoux, 2005). Instead, the present data point out a specific mediator that promotes amygdala neuron maturation to regulate how innate fear is initial formed in the developing brain. Combining with

A

E
B
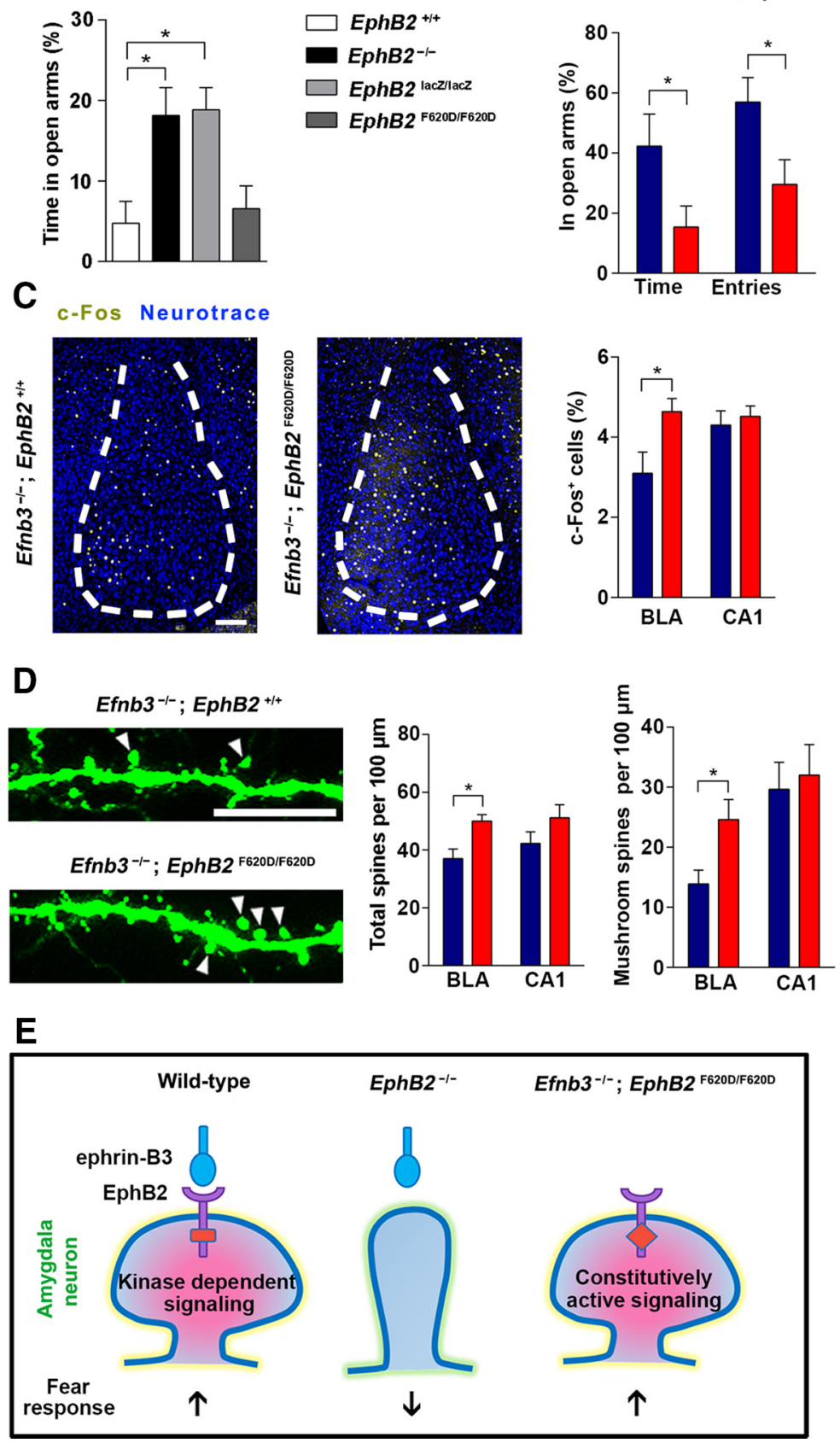

Figure 9. Constitutively active EphB2 kinase restores BLA neuron maturation and innate fear responses in ephrin-B3-null mice. $A, E p h B 2^{-1-}$ and $E p h B 2^{\text {lacZ/lacZ }}$ but not $E p h B 2^{\mathrm{F} 620 \mathrm{D} / \mathrm{F} 620 \mathrm{D}}$ mice spent significantly more time in the open arms than wild types at $P 16 . n=14-18$ mice for per group. $B, C$, Behavioral response of innate fear in the EPM and c-Fos activation in BLA and CA1 neurons from Efnb3 $3^{-1-} ; E p h B 2^{+/+}$and $E f n b 3^{-1-} ; E p h B 2^{F 62 D / F 620 D}$ mutants were quantified. $n=5-7$ mice for per group. $D$, Spine morphogenesis in BLA neurons from Efnb3 $3^{-1-} ; E p h B 2^{+/+}$and $E f n b 3^{-1-} ; E p h B 2^{\mathrm{F} 62 \mathrm{D} / \mathrm{F} 620 \mathrm{D}}$ mutants at P16. Quantification of

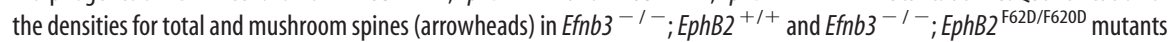
was performed at P16. $n=19-25$ neurons for per group. E, Summary model of EphB2 signal-mediated spinogenesis to generate innate fear responses. The presynaptic ephrin-B3 guides hippocampal axons to wire EphB2 receptor-expressing neurons in amygdala during the critical period. EphB2 receptor kinase activation consolidates the transsynaptic connection that is required for mushroom-type spinogenesis and threat-stimulated defensive responses in BLA neurons. Scale bars: $\boldsymbol{C}, 100 \mu \mathrm{m} ; \boldsymbol{D}, 5 \mu \mathrm{m}$. Data are presented as mean \pm SEM. ${ }^{*} p<0.05$.

our previous study on ligand like role of hippocampal ephrin-B3 for fear behavior generation (Zhu et al., 2016), our results thus identify specific key and lock molecules (ephrin-B3 and EphB2) that mediate a transnucleus signaling 
to control functional neural circuits and regulate innate behavior (Fig. 9E).

Previous findings have defined physiological roles of some specific neurons of the amygdala in fear and extinction behaviors (Yamada et al., 1999; Herry et al., 2008; Likhtik et al., 2008; Ciocchi et al., 2010; Haubensak et al., 2010), and most of them indicate that GABAergic neurons play a major role in emotional regulation. In contrast, our data reveal a critical role of the glutamatergic neurons in the neonatal brain for emotional behavior. A possible explanation for this difference is the timing and balance for the intrinsic modulation of functional neural circuit. Although it seems that the excitatory neurons may dominate earlier developmental periods while inhibitory neurons control the later complicated adult stage, the maintenance of the normal level of neural circuit activity in amygdala is due to precise balance of interaction between the two types of neurons as a whole (McDonald, 1982a). Our studies further reveal a specific developing window for the mushroom spinogenesis in amygdala that was coupled with its glutamatergic neuronal responses to aversive cues. The window of the spinogenesis-activation coupling in the developing brain structure is time limited. The evoked initial defensive responses rely on the morphological plasticity in mushroom-shaped spines.

This study also supports our previous presumption that tyrosine kinase activity of the EphB2 receptor in the postsynaptic BLA plays a major role upon cell-cell contact to receive the stimulation of ephrin-B3 in presynaptic axon terminals of CA1 (Zhu et al., 2016). Together with the accumulating evidence from previous studies (Sheffler-Collins and Dalva, 2012; Klein and Kania, 2014), the critical roles of EphB2 in neuronal development and synaptic function are involved in both the developing and adult brain. In view of the link of EphB2 signal deficit to anxiety disorders (Attwood et al., 2011), autism (Kong et al., 2012; Sanders et al., 2012), Angelman syndrome (Margolis et al., 2010), and cognitive dysfunction (Cissé et al., 2011), brain disorders accompanied by various emotional abnormalities, the current study may lead to an increased understanding of the molecular basis of the brain and emotion, and help bring about new insights for the treatment of these emotion-associated brain disorders.

\section{References}

Attwood BK, Bourgognon JM, Patel S, Mucha M, Schiavon E, Skrzypiec AE, Young KW, Shiosaka S, Korostynski M, Piechota M, Przewlocki R, Pawlak R (2011) Neuropsin cleaves EphB2 in the amygdala to control anxiety. Nature 473:372-375. CrossRef Medline

Bergado JA, Rojas Y, Capdevila V, Gonzalez O, Almaguer-Melian W (2006) Stimulation of the basolateral amygdala improves the acquisition of a motor skill. Restor Neurol Neurosci 24:115-121. Medline

Capogna M (2014) GABAergic cell type diversity in the basolateral amygdala. Curr Opin Neurobiol 26:110-116. CrossRef Medline

Chen ZY, Sun C, Reuhl K, Bergemann A, Henkemeyer M, Zhou R (2004) Abnormal hippocampal axon bundling in $\mathrm{EphB}$ receptor mutant mice. J Neurosci 24:2366-2374. CrossRef Medline

Chiapponi C, Piras F, Fagioli S, Piras F, Caltagirone C, Spalletta G (2013) Age-related brain trajectories in schizophrenia: a systematic review of structural MRI studies. Psychiatry Res 214:83-93. CrossRef Medline

Ciocchi S, Herry C, Grenier F, Wolff SB, Letzkus JJ, Vlachos I, Ehrlich I, Sprengel R, Deisseroth K, Stadler MB, Müller C, Lüthi A (2010) Encoding of conditioned fear in central amygdala inhibitory circuits. Nature 468:277-282. CrossRef Medline

Cissé M, Halabisky B, Harris J, Devidze N, Dubal DB, Sun B, Orr A, Lotz G, Kim DH, Hamto P, Ho K, Yu GQ, Mucke L (2011) Reversing EphB2 depletion rescues cognitive functions in Alzheimer model. Nature 469: 47-52. CrossRef Medline

Cruz E, Soler-Cedeño O, Negrón G, Criado-Marrero M, Chompré G, Porter JT (2015) Infralimbic EphB2 modulates fear extinction in adolescent rats. J Neurosci 35:12394-12403. CrossRef Medline
Dalva MB, Takasu MA, Lin MZ, Shamah SM, Hu L, Gale NW, Greenberg ME (2000) EphB receptors interact with NMDA receptors and regulate excitatory synapse formation. Cell 103:945-956. CrossRef Medline

Damsa C, Kosel M, Moussally J (2009) Current status of brain imaging in anxiety disorders. Curr Opin Psychiatry 22:96-110. CrossRef Medline

Dines M, Grinberg S, Vassiliev M, Ram A, Tamir T, Lamprecht R (2015) The roles of Eph receptors in contextual fear conditioning memory formation. Neurobiol Learn Mem 124:62-70.

Ethell IM, Irie F, Kalo MS, Couchman JR, Pasquale EB, Yamaguchi Y (2001) EphB/syndecan-2 signaling in dendritic spine morphogenesis. Neuron 31:1001-1013. CrossRef Medline

Fendt M, Endres T (2008) 2,3,5-Trimethyl-3-thiazoline (TMT), a component of fox odor - just repugnant or really fear-inducing? Neurosci Biobehav Rev 32:1259-1266. CrossRef Medline

Gold PE, Hankins L, Edwards RM, Chester J, McGaugh JL (1975) Memory interference and facilitation with posttrial amygdala stimulation: effect on memory varies with footshock level. Brain Res 86:509-513. CrossRef Medline

Gross CT, Canteras NS (2012) The many paths to fear. Nat Rev Neurosci 13:651-658. CrossRef Medline

Haubensak W, Kunwar PS, Cai H, Ciocchi S, Wall NR, Ponnusamy R, Biag J, Dong HW, Deisseroth K, Callaway EM, Fanselow MS, Lüthi A, Anderson DJ (2010) Genetic dissection of an amygdala microcircuit that gates conditioned fear. Nature 468:270-276. CrossRef Medline

Henderson JT, Georgiou J, Jia Z, Robertson J, Elowe S, Roder JC, Pawson T (2001) The receptor tyrosine kinase EphB2 regulates NMDA-dependent synaptic function. Neuron 32:1041-1056. CrossRef Medline

Henkemeyer M, Orioli D, Henderson JT, Saxton TM, Roder J, Pawson T, Klein R (1996) Nuk controls pathfinding of commissural axons in the mammalian central nervous system. Cell 86:35-46. CrossRef Medline

Henkemeyer M, Itkis OS, Ngo M, Hickmott PW, Ethell IM (2003) Multiple EphB receptor tyrosine kinases shape dendritic spines in the hippocampus. J Cell Biol 163:1313-1326. CrossRef Medline

Herry C, Ciocchi S, Senn V, Demmou L, Müller C, Lüthi A (2008) Switching on and off fear by distinct neuronal circuits. Nature 454:600-606. CrossRef Medline

Hindges R, McLaughlin T, Genoud N, Henkemeyer M, O’Leary D (2002) EphB forward signaling controls directional branch extension and arborization required for dorsal-ventral retinotopic mapping. Neuron 35: 475-487. CrossRef Medline

Holmberg J, Genander M, Halford MM, Annerén C, Sondell M, Chumley MJ, Silvany RE, Henkemeyer M, Frisén J (2006) EphB receptors coordinate migration and proliferation in the intestinal stem cell niche. Cell 125: 1151-1163. CrossRef Medline

Hoogenraad CC, Milstein AD, Ethell IM, Henkemeyer M, Sheng M (2005) GRIP1 controls dendrite morphogenesis by regulating EphB receptor trafficking. Nat Neurosci 8:906-915. CrossRef Medline

Jinno S, Klausberger T, Marton LF, Dalezios Y, Roberts JD, Fuentealba P, Bushong EA, Henze D, Buzsáki G, Somogyi P (2007) Neuronal diversity in GABAergic long-range projections from the hippocampus. J Neurosci 27:8790-8804. CrossRef Medline

Kania A, Klein R (2016) Mechanisms of ephrin-Eph signalling in development, physiology and disease. Nat Rev Mol Cell Biol 17:240-256. CrossRef Medline

Kayser MS, McClelland AC, Hughes EG, Dalva MB (2006) Intracellular and trans-synaptic regulation of glutamatergic synaptogenesis by EphB receptors. J Neurosci 26:12152-12164. CrossRef Medline

Kayser MS, Nolt MJ, Dalva MB (2008) EphB receptors couple dendritic filopodia motility to synapse formation. Neuron 59:56-69. CrossRef Medline

Klausberger T, Somogyi P (2008) Neuronal diversity and temporal dynamics: the unity of hippocampal circuit operations. Science 321:53-57. CrossRef Medline

Klein R (2009) Bidirectional modulation of synaptic functions by Eph/ephrin signaling. Nat Neurosci 12:15-20. CrossRef Medline

Klein R, Kania A (2014) Ephrin signalling in the developing nervous system. Curr Opin Neurobiol 27:16-24. CrossRef Medline

Kobayakawa K, Kobayakawa R, Matsumoto H, Oka Y, Imai T, Ikawa M, Okabe M, Ikeda T, Itohara S, Kikusui T, Mori K, Sakano H (2007) Innate versus learned odour processing in the mouse olfactory bulb. Nature 450:503-508. CrossRef Medline

Kong A, Frigge ML, Masson G, Besenbacher S, Sulem P, Magnusson G, Gud- 
jonsson SA, Sigurdsson A, Jonasdottir A, Jonasdottir A, Wong WS, Sigurdsson G, Walters GB, Steinberg S, Helgason H, Thorleifsson G, Gudbjartsson DF, Helgason A, et al. (2012) Rate of de novo mutations and the importance of father's age to disease risk. Nature 488:471-475. CrossRef Medline

LeDoux J (2003) The emotional brain, fear, and the amygdala. Cell Mol Neurobiol 23:727-738. CrossRef Medline

Likhtik E, Popa D, Apergis-Schoute J, Fidacaro GA, Paré D (2008) Amygdala intercalated neurons are required for expression of fear extinction. Nature 454:642-645. CrossRef Medline

Margolis SS, Salogiannis J, Lipton DM, Mandel-Brehm C, Wills ZP, Mardinly AR, Hu L, Greer PL, Bikoff JB, Ho HY, Soskis MJ, Sahin M, Greenberg ME (2010) EphB-mediated degradation of the RhoA GEF Ephexin5 relieves a developmental brake on excitatory synapse formation. Cell 143:442-455. CrossRef Medline

Mascagni F, McDonald AJ (2009) Parvalbumin-immunoreactive neurons and GABAergic neurons of the basal forebrain project to the rat basolateral amygdala. Neuroscience 160:805-812. CrossRef Medline

McDonald AJ (1982a) Cytoarchitecture of the central amygdaloid nucleus of the rat. J Comp Neurol 208:401-418. CrossRef Medline

McDonald AJ (1982b) Neurons of the lateral and basolateral amygdaloid nuclei: a Golgi study in the rat. J Comp Neurol 212:293-312. CrossRef Medline

McDonald AJ (1998) Cortical pathways to the mammalian amygdala. Prog Neurobiol 55:257-332. CrossRef Medline

Meyer-Lindenberg A, Hariri AR, Munoz KE, Mervis CB, Mattay VS, Morris CA, Berman KF (2005) Neural correlates of genetically abnormal social cognition in Williams syndrome. Nat Neurosci 8:991-993. CrossRef Medline

Morrow BA, Elsworth JD, Roth RH (2002) Fear-like biochemical and behavioral responses in rats to the predator odor, TMT, are dependent on the exposure environment. Synapse 46:11-18. CrossRef Medline

Nolt MJ, Lin Y, Hruska M, Murphy J, Sheffler-Colins SI, Kayser MS, Passer J, Bennett MV, Zukin RS, Dalva MB (2011) EphB controls NMDA receptor function and synaptic targeting in a subunit-specific manner. J Neurosci 31:5353-5364. CrossRef Medline

Penzes P, Beeser A, Chernoff J, Schiller MR, Eipper BA, Mains RE, Huganir RL (2003) Rapid induction of dendritic spine morphogenesis by transsynaptic ephrinB-EphB receptor activation of the Rho-GEF kalirin. Neuron 37:263-274. CrossRef Medline

Phelps EA, LeDoux JE (2005) Contributions of the amygdala to emotion processing: from animal models to human behavior. Neuron 48:175-187. CrossRef Medline

Pitkänen A, Pikkarainen M, Nurminen N, Ylinen A (2000) Reciprocal connections between the amygdala and the hippocampal formation, perirhinal cortex, and postrhinal cortex in rat. A review. Ann N Y Acad Sci 911:369-391. Medline

Robichaux MA, Chenaux G, Ho HY, Soskis MJ, Dravis C, Kwan KY, Šestan N, Greenberg ME, Henkemeyer M, Cowan CW (2014) EphB receptor forward signaling regulates area-specific reciprocal thalamic and cortical axon pathfinding. Proc Natl Acad Sci U S A 111:2188-2193. CrossRef Medline

Rodriguez A, Ehlenberger DB, Dickstein DL, Hof PR, Wearne SL (2008) Automated three-dimensional detection and shape classification of dendritic spines from fluorescence microscopy images. PLoS One 3:e1997. CrossRef Medline

Rosen JB, Pagani JH, Rolla KL, Davis C (2008) Analysis of behavioral constraints and the neuroanatomy of fear to the predator odor trimethylthiazoline: a model for animal phobias. Neurosci Biobehav Rev 32:1267-1276. CrossRef Medline

Sah P, Faber ES, Lopez De Armentia M, Power J (2003) The amygdaloid complex: anatomy and physiology. Physiol Rev 83:803-834. CrossRef Medline

Sanders SJ, Murtha MT, Gupta AR, Murdoch JD, Raubeson MJ, Willsey AJ, Ercan-Sencicek AG, DiLullo NM, Parikshak NN, Stein JL, Walker MF, Ober GT, Teran NA, Song Y, El-Fishawy P, Murtha RC, Choi M, Overton JD, Bjornson RD, Carriero NJ, et al. (2012) De novo mutations revealed by whole-exome sequencing are strongly associated with autism. Nature 485:237-241. CrossRef Medline

Senn V, Wolff SB, Herry C, Grenier F, Ehrlich I, Gründemann J, Fadok JP, Müller C, Letzkus JJ, Lüthi A (2014) Long-range connectivity defines behavioral specificity of amygdala neurons. Neuron 81:428-437. CrossRef Medline

Shamir A, Kwon OB, Karavanova I, Vullhorst D, Leiva-Salcedo E, Janssen MJ, Buonanno A (2012) The importance of the NRG-1/ErbB4 pathway for synaptic plasticity and behaviors associated with psychiatric disorders. J Neurosci 32:2988-2997. CrossRef Medline

Sheffler-Collins SI, Dalva MB (2012) EphBs: an integral link between synaptic function and synaptopathies. Trends Neurosci 35:293-304. CrossRef Medline

Smith Y, Paré JF, Paré D (2000) Differential innervation of parvalbuminimmunoreactive interneurons of the basolateral amygdaloid complex by cortical and intrinsic inputs. J Comp Neurol 416:496-508. Medline

Spampanato J, Polepalli J, Sah P (2011) Interneurons in the basolateral amygdala. Neuropharmacology 60:765-773. CrossRef Medline

Sun S, Zhang H, Liu J, Popugaeva E, Xu NJ, Feske S, White CL 3rd, Bezprozvanny I (2014) Reduced synaptic STIM2 expression and impaired storeoperated calcium entry cause destabilization of mature spines in mutant presenilin mice. Neuron 82:79-93. CrossRef Medline

Thornton-Wells TA, Avery SN, Blackford JU (2011) Using novel control groups to dissect the amygdala's role in Williams syndrome. Dev Cogn Neurosci 1:295-304. CrossRef Medline

Tolias KF, Bikoff JB, Kane CG, Tolias CS, Hu L, Greenberg ME (2007) The Rac1 guanine nucleotide exchange factor Tiam1 mediates EphB receptordependent dendritic spine development. Proc Natl Acad Sci U S\}A 104: 7265-7270. CrossRef Medline

Tye KM, Prakash R, Kim SY, Fenno LE, Grosenick L, Zarabi H, Thompson KR, Gradinaru V, Ramakrishnan C, Deisseroth K (2011) Amygdala circuitry mediating reversible and bidirectional control of anxiety. Nature 471:358-362. CrossRef Medline

Williams SE, Mann F, Erskine L, Sakurai T, Wei S, Rossi DJ, Gale NW, Holt CE, Mason CA, Henkemeyer M (2003) Ephrin-B2 and EphB1 mediate retinal axon divergence at the optic chiasm. Neuron 39:919-935. CrossRef Medline

Xu NJ, Sun S, Gibson JR, Henkemeyer M (2011) A dual shaping mechanism for postsynaptic ephrin-B3 as a receptor that sculpts dendrites and synapses. Nat Neurosci 14:1421-1429. CrossRef Medline

Yamada J, Saitow F, Satake S, Kiyohara T, Konishi S (1999) GABA(B) receptor-mediated presynaptic inhibition of glutamatergic and GABAergic transmission in the basolateral amygdala. Neuropharmacology 38 : 1743-1753. CrossRef Medline

Yamaguchi Y, Pasquale EB (2004) Eph receptors in the adult brain. Curr Opin Neurobiol 14:288-296. CrossRef Medline

Yokoyama N, Romero MI, Cowan CA, Galvan P, Helmbacher F, Charnay P, Parada LF, Henkemeyer M (2001) Forward signaling mediated by ephrin-B3 prevents contralateral corticospinal axons from recrossing the spinal cord midline. Neuron 29:85-97. CrossRef Medline

Zalla T, Sperduti M (2013) The amygdala and the relevance detection theory of autism: an evolutionary perspective. Front Hum Neurosci 7:894. Medline

Zhu XN, Liu XD, Sun S, Zhuang H, Yang JY, Henkemeyer M, Xu NJ (2016) Ephrin-B3 coordinates timed axon targeting and amygdala spinogenesis for innate fear behaviour. Nat Commun 7:11096. CrossRef Medline 